\section{Could altitude training benefit team-sport athletes?}

\author{
Olivier Girard, Hakim Chalabi
}

\section{INTRODUCTION}

Following the dominance of altitude acclimatised athletes during the 1968 Olympic Games held in Mexico City (2400 m), and early anecdotal training experiments in the USA in the 1970s, altitude (hypoxic) training has become very popular among individual endurance athletes including marathon runners, cyclists, swimmers and triathletes. Altitude training is used to further enhance exercise performance at sea level or to acclimatise to competition at altitude. The fundamental theory behind altitude training is simple; that is, by exposing an athlete to an environment that is low in oxygen, the body will eventually adapt to this stress and improve its efficiency at transporting and using oxygen. However, this may not be the only factor involved in the enhancement of performance since other central (eg, ventilation, haemodynamics or neural adaptations) and/or peripheral (eg, muscle-buffering capacity or economy) factors may also play an important role. ${ }^{1}$

There are many different altitude training strategies. ' 'Live high-train high', as do the East African runners who live and train at altitude. 'Live high-train low' invokes the beneficial effects of altitude while avoiding, first, the need for a decrease in training intensity and, second, the detrimental effects of chronic hypoxia. Altitude training in the form of 'live high-train low' was first demonstrated to improve athletic performance in the late 1990s. Since then, research into altitude training and its adaptive mechanisms has gained popularity, possibly because it offers performance benefits to athletes in the range $1-3 \%$. Other approaches also include intermittent hypoxic exposure at rest or during continuous training sessions, interval-training sessions and even 'live high-train low and high' or 'live high-train low in the heat'. Until now, however, reports of

Research and Education Centre, ASPETAR, Qatar Orthopaedic and Sports Medicine Hospital, Doha, Qatar Correspondence to Dr Olivier Girard, Research and Education Centre, ASPETAR, Qatar Orthopaedic and Sports Medicine Hospital, PO Box 29222, Doha, QATAR; oliv.girard@gmail.com performance improvement vary widely, and the efficiency of some of the abovelisted methods has not been thoroughly investigated. ${ }^{3}$

\section{ALTITUDE TRAINING AND THE TEAM-SPORT ATHLETES}

In recent times, media reports have provided us with coverage of several highprofile clubs undertaking training camps at altitude in an attempt to gain a competitive edge. Whether it be Australian football league teams in preparation for the upcoming season or national soccer squads preparing for the World Cup, athletes from different team sports worldwide are using altitude training more than ever before.

However, the majority of the research pertaining to the benefits of altitude training on performance at sea level until now has been conducted on individual endurance athletes. ${ }^{3}$ As such, the findings in this population cannot necessarily be generalised to team-sport athletes such as football players. There is almost a complete absence of research into the effects of altitude training in team sports, ${ }^{45}$ where aerobic capacity is less important than individual endurance sports such as long-distance running or cycling. Nevertheless, with many team sports regularly having international competitions at moderate altitude (Johannesburg, South Africa) or even high altitude (La Paz, Bolivia), the subject of acclimatisation and acclimation is of increasing international importance. ${ }^{67}$

Maximum strength and power during single actions are certainly not compromised by altitude; however, repeated bouts of highintensity efforts may be compromised, and this could determine the outcome of crucial situations. For instance, playing football above $1200 \mathrm{~m}$ during World Cup 2010 matches had negative effects on teams' endurance performance, as the total distance covered during the game was $\sim 3 \%$ lower than in matches at sea level. ${ }^{7}$

Altitude training has thus become an area of interest for major sport governing bodies. ${ }^{8} 9$ The Fédération Internationale de Football Association Medical Assessment and Research Centre-of which Aspetar
Hospital is one accredited Medical Centre of Excellence-and the International Olympic Committee Medical Commission have recognised that there is little research and no consensus on the effects of altitude training on the performance of teamsport athletes. All this begs the question: could altitude training benefit team-sport athletes?

\section{ASPETAR HOSPITAL}

Aspetar is the first specialised Orthopaedic and Sports Medicine Hospital in the Gulf region providing the highest possible medical treatment for sports-related injuries in a state-of-the-art facility. With its sandcovered plains, its very hot and humid summers and its highest point culminating at an altitude of only $\sim 100 \mathrm{~m}$, Qatar may not immediately be associated with cutting-edge research on altitude training. That said, Aspetar Hospital has world-class normobaric hypoxic facilities. The Aspetar altitude dormitory has 25 oxygen-deprived rooms with two beds each, enabling local or visiting teams to reside/sleep in comfort at a moderate altitude, while training near sea level or at simulated altitude utilising the other hypoxic facilities (eg, climatic chambers, mobile inflatable marquees). This is further enhanced by immediate access to world-class sports medicine and laboratory services to assist in athletes' physiological evaluation.

\section{THIS SUPPLEMENT}

The main objective of the Altitude Training and Team Sports conference held on 24-25 March 2013 in Doha, Qatar was to present cutting-edge research on the basic and applied aspects of altitude training. The conference featured over 25 presentations and hosted a total of 120 participants including athletes, coaches, sport scientists and a panel of world experts interested in the practical application of altitude training to enhance match-related performance in team sports. This event included discussions about the neuromuscular, metabolic and cardiovascular adaptations that occur in response to exercise and training in hypoxic environments. Strategies for developing peak performance and optimising the 'altitude dose' have been reviewed. Furthermore, eight young scientists have been invited to present their new research on the effects of chronic exposure to altitude on match-related performance in team-sport athletes. How elite coaching teams can incorporate the new evidence has also been discussed. Finally, a round- 
table meeting in which the panellists engaged in focused discussions resulted in a position statement paper with the aim of providing practical recommendations for coaching teams. This targeted issue of the British Journal of Sports Medicine highlights some key issues raised during the debates.

\section{MOVING FORWARD}

In the coming years, researchers and clinicians at Aspetar, in collaboration with leaders in the field of altitude training, aim to address the lack of research in this specific area by sorting fact from fiction and providing new knowledge to Gulf/ Middle-Eastern and international teamsport athletes.

Contributors OG was involved in the writing of the manuscript. HC was involved in the review and approval of the manuscript.

\section{Competing interests None.}

Provenance and peer review Not commissioned; internally peer reviewed.

\section{6 OPEN ACCESS}

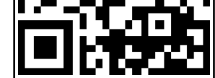

Open Access

can to access mo

free content

Open Access This is an Open Access article distributed in accordance with the Creative Commons Attribution Non Commercial (CC BY-NC 3.0) license, which permits others to distribute, remix, adapt, build upon this work non-commercially, and license their derivative works on different terms, provided the original work is properly cited and the use is noncommercial. See: http://creativecommons.org/licenses/ by-nc/3.0/

To cite Girard O, Chalabi H. Br I Sports Med 2013;47:i4-i5.

Accepted 26 July 2013

Br J Sports Med 2013;47:i4-i5.

doi:10.1136/bjsports-2013-092807

\section{REFERENCES}

1 Millet GP, Roels B, Schmitt L, et al. Combining hypoxic methods for peak performance. Sports Med 2010:40:1-25.
2 Lundby C, Millet GP, Calbet JA, et al. Does 'altitude training' increase exercise performance in elite athletes? Br J Sports Med 2012;46: 792-5.

3 Billaut F, Gore CJ, Aughey RJ. Enhancing team-sport athlete performance: is altitude training relevant? Sports Med 2012;42:751-67.

4 Morton JP, Cable NT. Effects of intermittent hypoxic training on aerobic and anaerobic performance. Ergonomics 2005;48:1535-46.

5 Hamlin MJ, Hinckson EA, Wood MR, et al. Simulated rugby performance at $1550-\mathrm{m}$ altitude following adaptation to intermittent normobaric hypoxia. J Sci Med Sport 2008;11:593-9.

6 Garvican L, Hammond K, Varley MC, et al. Lower running performance and exacerbated fatigue in soccer played at $1600 \mathrm{~m}$. Int I Sport Physiol Perf 22 May 2013 [Epub ahead of print].

7 Nassis GP. Effects of altitude on football performance: analysis of the 2010 FIFA Wold Cup Data. J Strength Cond Res 2013:27:703-7.

8 Bartsch P, Saltin B, Dvorak J. Consensus statement on playing football at different altitude. Scand I Med Sci Sports 2008;18:96-9.

9 Bergeron MF, Bahr R, Bartsch P, et al. International Olympic Committee consensus statement on thermoregulatory and altitude challenges for high-level athletes. Br J Sports Med 2012;46:770-9. 